\title{
PENGARUH PEMBELAJARAN KONSTRUKTIVISME TERHADAP KEMAMPUAN MENULIS SISWA PADA MATA PELAJARAN BAHASA INDONESIA KELAS V SD NEGERI MANGASA I KECAMATAN SOMBA OPU KABUPATEN GOWA
}

\author{
Evi Sarpika, Hambali, Tarman A. Arief \\ Pendidikan Guru Sekolah Dasar, Fakultas Keguruan dan Ilmu Pendidikan \\ Universitas Muhammadiyah Makassar \\ Iqramsyar34@gmail.com
}

\begin{abstract}
ABSTRAK
Penelitian ini bertujuan untuk mendeskripsikan Pengaruh Pembelajaran Konstruktivisme terhadap Kemampuan Menulis Siswa pada Mata Pelajaran Bahasa Indonesia Siswa Kelas V SD Negeri Mangasa I Kecamatan Somba Opu Kabupaten Gowa. Jenis penelitian yang digunakan dalam penelitian ini adalah jenis penelitian pre eksperimental dengan jenis one group pre test-post test design. Desain ini melakukan dua kali pengukuran terhadap pemahaman siswa tentang materi yang akan dijadikan sampel. Pengukuran pertama (pre test) dilakukan untuk melihat kondisi sampel sebelum diberikan perlakukan, yaitu tingkat pemahaman siswa kelas $\mathrm{V}$ sebelum diterapkan pembelajaran konstruktivisme dan pengukuran kedua (post test) dilakukan pembelajaran konstruktivisme untuk mengetahui tingkat pemahaman siswa kelas V setelah diterapkan oleh peneliti. Subjek dalam penelitian ini adalah murid kelas V Sd Negeri Mangasa I sebanyak 30 orang. Hasil penelitian ini menunjukkan bahwa penggunaan pembelajaran konstruktivisme pada kemampuan menulis pada mata pelajaran bahasa Indonesia siswa kelas V SD Negeri Mangasa I Kecamatan Somba Opu Kabupaten Gowa berpengaruh. Hal ini tampak pada tingkat kemampuan siswa sebelum menggunakan model pembelajaran yaitu rata-ratanya hanya mencapai 60,83. Selanjutnya setelah menggunakan pembelajaran konstruktivisme nilai rata-rata yang diperoleh sebesar 87,5 hal ini berarti bahwa tingkat kemampuan siswa meningkat. Pengaruh pembelajaran konstruktivisme diketahui pula berdasarkan hasil perhitungaan uji $t$. Hasil penelitian diperoleh, $t_{\text {Hitung }}=18,51$ dan $t_{\text {Tabel }}=2,04$ maka $t_{\text {Hitung }} \geq t_{\text {Tabel }}$ atau 18,51 $\geq 2,04$. Sehingga dapat disimpulkan bahwa Ho di tolak dan $\mathrm{H}_{1}$ diterima. Ini berarti bahwa pembelajaran konstruktivisme memberikan pengaruh positif yang signifikan..
\end{abstract}

Kata Kunci: konstruktivisme; kemampuan menulis 


\section{PENDAHULUAN}

Dalam pembelajaran Bahasa dan Sastra Indonesia ada empat kompetensi atau kemampuan yang harus dikuasai siswa pada setiap jenjang pendidikan. Adapun keempat kemampuan tersebut adalah menyimak, berbicara, membaca, dan menulis. Masing-masing kemampuan ini saling mempengaruhi.

Sebagai suatu keterampilan berbahasa kemampuan menyimak dapat diperoleh secara "alamiah" berbeda dengan kemampuan menulis. Pada kemampuan menulis ini harus dipelajari dan dilatih secara sungguh-sungguh sehingga dapat meningkatkan mutu pendidikan terutama pada pendidikan bahasa Indonesia.

Pola pembelajaran menulis yang dikembangkan sangat berstruktur dan mekanis, mulai dari penentuan topik, penyeragaman kerangka tidaklah selamanya bijaksana. Dengan adanya penyeragaman topik, penyeragaman pola, menyebabkan kreativitas siswa menjadi kurang berkembang. Peserta didik merasa materi tersebut asing karena skemata/informasi awal tentang tema/topik yang akan ditulis tersebut kurang memadai. Akibatnya, pembelajaran menulis menjadi kering, tidak menarik, tidak alamiah, dan tidak bermakna. Siswa akan kehilangan gairah dalam mengikuti pembelajaran menulis sehingga keterampilan peserta didik dalam menulis menjadi terhambat. Tompkins (1994: 105), menyatakan terlalu menuntut kesempurnaan hasil tulisan dari peserta didik justru dapat menghentikan kemauan siswa untuk menulis.

Oleh karena itu, peneliti berkolaborasi dengan guru kelas untuk merancang sebuah pembelajaran yang mampu membuat peserta didik termotivasi selama mengikuti proses belajar-mengajar. Salah satu alternatif dalam penelitian ini, yaitu dengan menerapkan metode pembelajaran konstruktivisme. Metode konstruktivisme ini dikembangkan oleh Piaget dan Vigotsky (Suyatno, 2004:33) yang menekankan bahwa perubahan kognitif hanya terjadi jika konsepsi-konsepsi yang telah dipahami sebelumnya diolah melalui proses ketidakseimbangan dalam upaya memperoleh informasi baru. Pembelajaran dengan metode konstruktivisme ini digunakan agar siswa mampu menemukan masalah (sering muncul dari siswa sendiri) dan selanjutnya membantu siswa menyelesaikan dan menemukan langkah-langkah pemecahan masalah.

Dengan menyoroti latar belakang tersebut, metode konstruktivisme dipilih sebagai alternatif dalam pengajaran dalam menulis dan karena metode ini dianggap 
sebagai cara yang efektif untuk mengarahkan seluruh potensi siswa sehingga siswa lebih termotivasi selama mengikuti proses belajar-mengajar yang berdampak positif pada hasil belajarnya.

Berdasarkan uraian tersebut, maka dapat ditegaskan bahwa dalam pembelajaran konstruktivisme memiliki pengaruh terhadap kemampuan menulis siswa. Oleh karena itu, penulis tertarik untuk mengangkat judul "Pengaruh Pembelajaran Konstruktivisme terhadap Kemampuaan Menulis Siswa pada Mata Pelajaran Bahasa Indonesia Kelas V SDN Mangasa I Kecematan Somba Opu Kabupaten Gowa".

Berdasarkan uraian di atas rumusan masalah dalam penelitian ini adalah: “Apakah pembelajaran konstruktivisme berpengaruh terhadap kemampuan menulis siswa pada mata pelajaran bahasa Indonesia kelas V SDN Mangasa I Kecematan Somba Opu Kabupaten Gowa?". tujuan penelitian ini adalah untuk mengetahui pengaruh pembelajaran konstruktivisme terhadap kemampuan menulis siswa pada mata pelajaran bahasa Indonesia kelas V SDN Mangasa I Kecematan Somba Opu Kabupaten Gowa.

\section{Hakikat Menulis}

Menulis adalah penyampaian pesan (gagasan, perasaan dan informasi) secara tertulis kepada pihak lainnya sebagai salah satu bentuk keunikan verbal, menulis melibatkan unsur penulis sebagai penyampaian pesan, atau isi tulisan, saluran atau medium tulisan dan pembaca sebagai penerima pesan.

Robert Lodo (Suriamiaharja, 1996: 1) mengatakan bahwa menulis adalah menempatkan simbol-simbol grafik yang menggambarkan suatu bahasa yang dimengerti oleh seseorang, kemudian dapat dibaca oleh orang lain yang memahami bahasa tersebut beserta simbol-simbol grafiknya.

Pengertian menulis juga dikemukakan oleh Suparno dan Yunus, (2007: 4) bahwa, "Menulis adalah aktivitas menyampaikan pesan dengan menggunakan tulisan sebagai medianya. Menghasilkan pesan tertulis yang komunikatif diperlukan persyaratan yang harus dipenuhi, diantaranya bermakna, jelas, lugas, atau kesatuan, singkat tetapi padat serta memenuhi kaidah kebahasaan" (Akhadiah, 1991: 103).

Dari beberapa teori di atas calon peneliti dapat menyimpulkan bahwa dengan tulisan dapat terjadi komunikasi antara penulis dan pembaca memahami lambang- 
lambang grafik yang dipergunakan untuk menulis tersebut. Misalnya seseorang dapat dikatakan sedang menulis huruf latin jika seseorang tersebut memahami lambang grafik dari huruf latin tersebut, demikian pula seseorang dapat dikatakan sedang menulis huruf arab apabila orang tersebut memahami lambang dan grafik dari huruf arab. Dalam hal ini seseorang tidak dapat dikatakan sedang menulis huruf latin atau huruf arab jika orang tersebut tidak memahami lambang grafik dari kedua huruf tersebut.

\section{Hakikat pembelajaran konstruktivisme}

Kontruktivisme adalah membangun pemahaman dari diri pembelajar sendiri menjadi pengalaman dan wawasan baru berdasarkan pada pengetahuan awal. Pembelajaran harus dikemas menjadi proses "mengontruksi" bukan menerima pengetahuan.

Kontruktivisme merupakan pendekatan pembelajaran yang berorientasi pada terbangunnya pemahaman dan pengetahuan sendiri secara aktif, kreatif, inovatif, inspiratif dan produktif berdasarkan pengetahuan terdahulu dan dari pengalaman belajar yang bermakna.

Karli (2003:2) menyatakan konstruktivisme adalah salah satu pandangan tentang proses pembelajaran yang menyatakan bahwa dalam proses belajar (perolehan pengetahuan) diawali dengan terjadinya konflik kognitif yang hanya dapat diatasi melalui pengetahuan diri dan pada akhir proses belajar pengetahuan akan dibangun oleh anak melalui pengalamannya dari hasil interkasi dengan lingkungannya.

a. Prinsip-Prinsip Pembelajaran Konstruktivisme

Prinsip-prinsip Konstruktivisme yang diterapkan dalam belajar mengajar:

1.) Pengetahuan dibangun oleh siswa sendiri

2.) Pengetahuan tidak dapat dipindahkan dari guru kemurid, kecuali hanya dengan keaktifan murid sendiri untuk menalar

3.) Murid aktif megkontruksi secara terus menerus, sehingga selalu terjadi perubahan konsep ilmiah

4.) Guru sekedar membantu menyediakan saran dan situasi agar proses kontruksi berjalan lancar.

5.) Menghadapi masalah yang relevan dengan siswa 
6.) Struktur pembalajaran seputar konsep utama pentingnya sebuah pertanyaan

7.) Mencari dan menilai pendapat siswa

8.) Menyesuaikan kurikulum untuk menanggapi anggapan siswa.

\section{METODE PENELITIAN}

Pendekatan yang digunakan dalam penelitian ini adalah pendekatan eksperimen yang bersifat kuantitatif. Jenis penelitian yang dilakukan dalam penelitian ini adalah PreExperimental Design, yang mengkaji pengaruh pembelajaran Konstruktivisme. Desain Experimen yang digunakan adalah One-Group Pretest-Posttest Design.

Populasi dalam penelitian ini adalah seluruh siswa kelas V SDN Mangasa I tahun ajaran 2016/2017 yang berjumlah 30 orang. sampel dalam penelitian ini adalah murid kelas V karena ditemukan masalah yaitu rendahnya kemampuan menulis siswa. Analisis data penelitian dimaksudkan untuk menganalisis data hasil tes penelitian berkaitan dengan Pembelajaran Konstruktivisme yang telah diterapkan, teknik analisis data yang digunakan adalah analisis deskriftif dan analisis t-tets.

\section{HASIL PENELITIAN DAN PEMBAHASAN}

\section{Deskripsi Hasil Pretest Bahasa Indonesia Siswa Kelas V SD Negeri Mangasa I}

Sebelum melakukan penelitian, peneliti melakukan observasi untuk mencari nilai awal (pre test) siswa sebelum diberikan perlakuan.

Untuk mencari mean (rata-rata) nilai pre-test dari siswa kelas V SD Negeri Mangasa I Kecamatan Somba Opu Kabupaten Gowa dapat dilihat melalui tabel di bawah ini:

Tabel 4.1. Perhitungan untuk mencari mean ( rata - rata ) nilai pretest

\begin{tabular}{|c|c|c|}
\hline $\mathbf{X}$ & $\mathbf{F}$ & $\mathbf{F . X}$ \\
\hline 40 & 2 & 80 \\
\hline 50 & 4 & 200 \\
\hline 55 & 5 & 275 \\
\hline 60 & 4 & 240 \\
\hline 65 & 5 & 325 \\
\hline 70 & 5 & 300 \\
\hline 75 & 1 & 75 \\
\hline
\end{tabular}




\begin{tabular}{|c|c|c|}
\hline 80 & 2 & 160 \\
\hline 85 & 2 & 170 \\
\hline Jumlah & $\mathbf{3 0}$ & $\mathbf{1 . 8 2 5}$ \\
\hline
\end{tabular}

Dari data di atas dapat diketahui bahwa nilai dari $\sum f x=1825$, sedangkan nilai dari $\mathrm{N}$ sendiri adalah 30 . Oleh karena itu, dapat diperoleh nilai rata-rata (mean) sebagai berikut:

$$
\begin{aligned}
\bar{x} & =\frac{\sum_{i=1}^{k} f x_{i}}{n} \\
& =\frac{1825}{30} \\
& =60,83
\end{aligned}
$$

Dari hasil perhitungan di atas maka diperoleh nilai rata-rata dari hasil belajar siswa kelas V SD Negeri Mangasa I Kecamatan Somba Opu Kabupaten Gowa sebelum penerapan pembelajaran konstrutivisme yaitu 60,83.

\subsection{Tingkat hasil belajar pre test}

\begin{tabular}{|c|c|c|c|c|}
\hline No & Interval & Frekuensi & $\begin{array}{c}\text { Persentase } \\
\mathbf{( \% )}\end{array}$ & $\begin{array}{c}\text { Kategori Hasil } \\
\text { Belajar }\end{array}$ \\
\hline 1 & $0-59$ & 11 & $36,6 \%$ & Sangat Kurang \\
\hline 2 & $60-69$ & 9 & $30 \%$ & Kurang \\
\hline 3 & $70-79$ & 6 & $20 \%$ & Cukup \\
\hline 4 & $80-89$ & 4 & $13,3 \%$ & Baik \\
\hline 5 & $90-100$ & - & $0 \%$ & Sangat Baik \\
\hline & Jumlah & 30 & 100 & \\
\hline
\end{tabular}

Berdasarkan data yang dapat dilihat pada tabel di atas maka dapat disimpulkan bahwa hasil belajar siswa pada tahap pretest dengan menggunakan instrumen test dikategorikan sangat rendah yaitu 36,6\%, rendah 30\%, sedang 20\%, tinggi 13,3\% dan sangat tingggi berada pada presentase $0 \%$. Melihat dari hasil presentase yang ada dapat dikatakan bahwa tingkat hasil belajar siswa sebelum diterapkan pembelajaran konstruktivisme.

\section{Tabel 4.3.Deskripsi Ketuntasan Hasil Belajar Bahasa Indonesia}




\begin{tabular}{|l|l|c|c|}
\hline \multicolumn{1}{|c|}{ Skor } & Kategorisasi & Frekuensi & $\begin{array}{c}\text { Persentase } \\
\text { (\%) }\end{array}$ \\
\hline $0 \leq x<70$ & Tidak tuntas & 20 & $66,6 \%$ \\
\hline $70 \leq \times \leq 100$ & Tuntas & 10 & $33,3 \%$ \\
\hline \multicolumn{2}{|r|}{ Jumlah } & 30 & 100 \\
\hline
\end{tabular}

Apabila Tabel 4.4 dikaitkan dengan indikator kriteria ketuntasan hasil belajar siswa yang ditentukan oleh peneliti yaitu jika jumlah siswa yang mencapai atau melebihi nilai KKM (70) $\geq 75 \%$, sehingga dapat disimpulkan bahwa hasil belajar siswa kelas V SD Negeri Mangasa I Kecamatan Somba Opu Kabupaten Gowa belum memenuhi kriteria ketuntasan hasil belajar secara klasikal karena siswa yang tuntas hanya $33,3 \% \leq 75 \%$.

\section{Deskripsi Hasil Belajar (Posttest) Bahasa Indonesia Siswa kelas V SD Negeri Mangasa I Kecamatan Somba Opu Kabupaten Gowa}

Selama penelitian berlangsung terjadi perubahan terhadap kelas setelah diberikan perlakuan. Perubahan tersebut berupa hasil belajar yang datanya diperoleh setelah diberikan post- test.

. Untuk mencari mean (rata-rata) nilai pre-test dari siswa kelas V SD Negeri Mangasa I Kecamatan Somba Opu Kabupaten Gowa dapat dilihat melalui tabel di bawah ini:

Tabel 4.4. Perhitungan untuk mencari mean ( rata - rata ) nilai posttest

\begin{tabular}{|c|c|c|}
\hline $\mathbf{X}$ & $\mathbf{F}$ & F.X \\
\hline 65 & 3 & 195 \\
\hline 70 & 1 & 70 \\
\hline 75 & 1 & 75 \\
\hline 80 & 2 & 160 \\
\hline 85 & 6 & 510 \\
\hline 90 & 6 & 540 \\
\hline 95 & 5 & 475 \\
\hline 100 & 6 & 600 \\
\hline
\end{tabular}




\begin{tabular}{|l|l|l|} 
Jumlah & 30 & 2625 \\
\hline
\end{tabular}

Dari data di atas dapat diketahui bahwa nilai dari $\sum f x=2625$, sedangkan nilai dari $\mathrm{N}$ sendiri adalah 30 . Oleh karena itu, dapat diperoleh nilai rata-rata (mean) sebagai berikut:

$$
\begin{aligned}
\bar{x} & =\frac{\sum_{i=1}^{k} f x_{i}}{n} \\
& =\frac{2625}{30} \\
& =87,5
\end{aligned}
$$

Dari hasil perhitungan di atas maka diperoleh nilai rata-rata dari hasil belajar siswa kelas V SD Negeri Mangasa I setelah penerapan pembelajaran konstruktivisme 87,5 .

\subsection{Tingkat hasil belajar Post-test}

\begin{tabular}{|c|c|c|c|c|}
\hline No & Interval & Frekuensi & $\begin{array}{c}\text { Persentase } \\
\mathbf{( \% )}\end{array}$ & $\begin{array}{c}\text { Kategori Hasil } \\
\text { Belajar }\end{array}$ \\
\hline 1 & $0-59$ & - & $0 \%$ & Sangat rendah \\
\hline 2 & $60-69$ & 3 & $10 \%$ & Rendah \\
\hline 3 & $70-79$ & 2 & $6,6 \%$ & Sedang \\
\hline 4 & $80-89$ & 8 & $26,6 \%$ & Tinggi \\
\hline 5 & $90-100$ & 17 & $56,6 \%$ & Sangat Tinggi \\
\hline & Jumlah & 30 & 100 & \\
\hline
\end{tabular}

Berdasarkan data yang dapat dilihat pada tabel di atas maka dapat disimpulkan bahwa hasil belajar siswa pada tahap post-test dengan menggunakan instrumen test dikategorikan sangat rendah yaitu $0 \%$, rendah $10 \%$, sedang $6,6 \%$, tinggi $26,6 \%$ dan sangat tingggi berada pada presentase 56,6\%. Melihat dari hasil presentase yang ada dapat dikatakan bahwa hasil belajar siswa sebelum diterapkan pembelajaran konstruktivisme.

Tabel 4.6. Deskripsi Ketuntasan Hasil Belajar Bahasa Indonesia

\begin{tabular}{|l|c|c|c|}
\hline \multicolumn{1}{|c|}{ Skor } & Kategorisasi & Frekuensi & $\begin{array}{c}\text { Presenta } \\
\text { se(\%) }\end{array}$ \\
\hline $0 \leq \times<70$ & Tidak tuntas & 3 & $10 \%$ \\
\hline
\end{tabular}




\begin{tabular}{|c|c|c|c|}
\hline $70 \leq \times \leq 100$ & Tuntas & 27 & $90 \%$ \\
\hline \multicolumn{2}{|c|}{ Jumlah } & 30 & 100 \\
\hline
\end{tabular}

Apabila Tabel 4.8 dikaitkan dengan indikator kriteria ketuntasan hasil belajar siswa yang ditentukan oleh peneliti yaitu jika jumlah siswa yang mencapai atau melebihi nilai KKM (70) $\geq 75 \%$, sehingga dapat disimpulkan bahwa hasil belajar siswa kelas V SD Negeri Mangasa I Kecamatan Somba Opu Kabupaten Gowa telah memenuhi kriteria ketuntasan hasil belajar secara klasikal karena siswa yang tuntas adalah 90\% $\leq 75 \%$.

\section{Pengaruh Penerapan Pembelajaran Konstruktivisme Terhadap Hasil Belajar Bahasa} Indonesia Pada Siswa Kelas V SD Negeri Mangasa I Kecamatan Somba Opu Kabupaten Gowa

Sesuai dengan hipotesis penelitian yakni "ada pengaruh dalam menerapkan pembelajaran konstruktivisme terhadap hasil belajar bahasa Indonesia pada siswa kelas V SD Negeri Mangasa I Kecamatan Somba Opu Kabupaten Gowa”. Maka teknik yang digunakan untuk menguji hipotesis tersebut adalah teknik statistik inferensial dengan menggunakan uji-t.

Tabel 4.7. Analisis skor Pre-test dan Post-test

\begin{tabular}{|c|l|l|l|l|}
\hline No & X1 (Pre-test) & $\mathbf{X 2 ( P o s t - t e s t )}$ & $\mathbf{d}=\mathbf{X 2}-\mathbf{X 1}$ & $\mathbf{d}^{2}$ \\
\hline 1 & 55 & 85 & 30 & 900 \\
\hline 2 & 75 & 90 & 15 & 225 \\
\hline 3 & 50 & 85 & 35 & 1225 \\
\hline 4 & 70 & 95 & 25 & 625 \\
\hline 5 & 65 & 90 & 25 & 625 \\
\hline 6 & 60 & 85 & 25 & 625 \\
\hline 7 & 85 & 100 & 15 & 225 \\
\hline 8 & 40 & 65 & 25 & 625 \\
\hline 9 & 55 & 90 & 35 & 4225 \\
\hline 10 & 50 & 70 & 20 & \\
\hline
\end{tabular}




\begin{tabular}{|l|l|l|l|l|}
\hline 11 & 80 & 100 & 20 & 400 \\
\hline 12 & 60 & 95 & 35 & 1225 \\
\hline 13 & 55 & 85 & 30 & 900 \\
\hline 14 & 50 & 65 & 15 & 225 \\
\hline 15 & 55 & 65 & 10 & 100 \\
\hline 16 & 65 & 100 & 35 & 1225 \\
\hline 17 & 80 & 100 & 20 & 400 \\
\hline 18 & 70 & 90 & 20 & 400 \\
\hline 19 & 55 & 75 & 20 & 400 \\
\hline 20 & 65 & 95 & 30 & 900 \\
\hline 21 & 70 & 90 & 20 & 400 \\
\hline 22 & 65 & 95 & 30 & 900 \\
\hline 23 & 60 & 85 & 25 & 625 \\
\hline 24 & 40 & 80 & 40 & 1600 \\
\hline 25 & 85 & 100 & 15 & 225 \\
\hline 26 & 50 & 80 & 30 & 900 \\
\hline 27 & 70 & 90 & 20 & 400 \\
\hline 28 & 70 & 100 & 30 & 900 \\
\hline 29 & 60 & 55 & 25 & 625 \\
\hline 30 & $\sum \mathbf{x}_{\mathbf{1}} \mathbf{1 8 2 5}$ & $\sum \mathbf{x}_{\mathbf{2}}=\mathbf{2 6 2 5}$ & $\mathbf{7 5 0}$ & 900 \\
\hline Jumlah & & $\mathbf{2 0 3 5 0}$ \\
\hline
\end{tabular}

Langkah-langkah dalam pengujian hipotesis adalah sebagai berikut:

1. Mencari harga "Md" dengan menggunakan rumus:

$$
\begin{aligned}
\mathrm{Md} & =\frac{\sum d}{N} \\
& =\frac{750}{30}
\end{aligned}
$$




$$
=25
$$

Mencari harga " $\sum X^{2} d$ " dengan menggunakan rumus:

$$
\begin{aligned}
\sum X^{2} d & =\sum d^{2}-\frac{\left(\sum d\right)^{2}}{N} \\
& =20350-\frac{(750)^{2}}{30} \\
& =20350-\frac{562500}{30} \\
& =20350-18750 \\
& =1600
\end{aligned}
$$

2. Menentukan harga $t_{\text {Hitung }}$

$$
\begin{array}{ll}
\mathrm{t} & =\frac{M d}{\sqrt{\frac{\sum X^{2} d}{N(N-1)}}} \\
\mathrm{t} & =\frac{25}{\sqrt{\frac{1600}{30(30-1)}}} \\
\mathrm{t} & =\frac{25}{\sqrt{\frac{1600}{870}}} \\
\mathrm{t} & =\frac{25}{\sqrt{1,83}} \\
\mathrm{t} & =\frac{25}{1,35} \\
\mathrm{t} & =18,51
\end{array}
$$

3. Menentukan harga $t_{\text {Tabel }}$

Untuk mencari $\mathrm{t}$ Tabel peneliti menggunakan table distribusi $\mathrm{t}$ dengan taraf signifikan $\alpha=0,05$ dan $d . b=N-1=30-1=29$ maka diperoleh $\mathrm{t}_{0,05}=2,04$

Setelah diperoleh $\mathrm{t}_{\text {Hitung }}=18,51$ dan $\mathrm{t}_{\text {Tabel }}=2,04$ maka diperoleh $\quad \mathrm{t}_{\text {Hitung }}>$ $\mathrm{t}_{\text {Tabel }}$ atau 18,51 > 2,04. Sehingga dapat disimpulkan bahwa $\mathrm{H}_{0}$ ditolak dan $\mathrm{H}_{1}$ diterima. Ini berarti bahwa ada pengaruh dalam menerapkan pengaruh penerapan pembelajaran konstruktivisme terhadap kemampuan menulis bahasa Indonesia pada siswa kelas V SD Negeri Mangasa I Kecamatan Somba Opu Kabupaten Gowa. 
Berdasarkan hasil pre-test, nilai rata-rata hasil belajar siswa 60,83 dengan kategori yakni sangat rendah yaitu 36,6\%, rendah 30\%, sedang 20\%, tinggi 13,3\% dan sangat tingggi berada pada presentase $0 \%$. Melihat dari hasil presentase yang ada dapat dikatakan bahwa tingkat hasil belajar siswa sebelum diterapkan metode diskusi tergolong rendah.

Selanjutnya nilai rata-rata hasil post-test adalah 87,5 jadi hasil belajar siswa setelah diterapkan pembelajaran konstruktivisme mempunyai hasil belajar yang lebih baik dibanding dengan sebelum penerapan pembelajaran konstruktivisme. Selain itu persentasi kategori hasil belajar bahasa Indonesia siswa juga meningkat yakni sangat rendah yaitu $0 \%$, rendah $10 \%$, sedang 6,6\%, tinggi $26,6 \%$ dan sangat tingggi berada pada presentase $56,6 \%$.

Berdasarkan hasil analisis statistik inferensial dengan menggunakan rumus uji t, dapat diketahui bahwa nilai thitung sebesar 18,51. Dengan frekuensi (dk) sebesar 30 $1=29$, pada taraf signifikansi $5 \%$ diperoleh $t_{\text {tabel }}=2,04$. Oleh karena $t_{\text {hitung }}>t_{\text {tabel }}$ pada taraf signifikansi 0,05 , maka hipotesis nol $\left(\mathrm{H}_{0}\right)$ ditolak dan hipotesis alternative $\left(\mathrm{H}_{1}\right)$ diterima yang berarti bahwa ada pengaruh dalam menerapkan pembelajaran konstruktivisme

Hasil analisis diatas yang menunjukkan adanya pengaruh penerapan pembelajaran konstruktivisme terhadap kemapuan menulis siswa sejalan dengan hasil observasi yang dilakukan. Berdasarkan hasil observasi terdapat perubahan pada siswa yaitu pada awal kegiatan pembelajaran ada beberapa siswa yang melakukan kegiatan lain atau bersikap cuek selama pembelajaran berlangsung. Hal ini dapat dilihat pada pertemuan pertama siswa yang melakukan kegiatan lain sebanyak 3 orang, sedangkan pada pertemuan terakhir hanya 1 siswa yang melakukan kegiatan lain pada saat penerapan model pembelajaran konstruktivisme berlangsung. Pada awal pertemuan, hanya sedikit siswa yang aktif mengikuti pembelajaran. Akan tetapi sejalan dengan diterapkannya pendekatan pembelajaran konstruktivisme siswa mulai aktif pada setiap pertemuan.

Hasil observasi menunjukkan banyaknya jumlah siswa yang menjawab pada saat diajukan pertanyaan dan siswa yang mengajukan diri untuk menyampaikan persoalan faktual. Siswa juga mulai aktif dan percaya diri untuk menyampaikan perasaan dan pendapatnya setelah melakukan kegiatan menulis cerita, mereka 
mengaku senang dan sangat menikmati yang dilakukan sehingga termotivasi untuk mengikuti pelajaran. Proses pembelajaran yang menyenangkan membuat siswa tidak lagi keluar masuk pada saat pembelajaran berlangsung dan tidak lagi merasa bosan ataupun tertekan ketika mengikuti proses pembelajaran di kelas.

Berdasarkan hasil analisis statistik deskriptif dan statistik inferensial yang diperoleh serta hasil observasi yang telah dilakukan, dapat disimpulkan bahwa ada pengaruh penerapan pembelajaran konstruktivisme terhadap kemampuan menulis bahasa Indonesia pada siswa kelas V SD Negeri Mangasa I Kecamatan Somba Opu Kabupaten Gowa.

\section{SIMPULAN DAN SARAN}

Berdasarkan hasil penelitian yang dilakukan tentang pengembangan model pembelajaran Predict, Observe, Discuss, dan Explain (PODE) untuk mata pelajaran IPA di SDN Kompleks IKIP Makassar, maka dapat disimpulkan: Berdasarkan uji hipotesis yang telah dilakukan dapat disimpulkan bahwa penerapan pembelajaran konstruktivisme berpengaruh terhadap hasil belajar. Berdasarkan hasil pre-test, nilai rata-rata hasil belajar siswa 60,83 dengan kategori yakni sangat rendah yaitu 36,6\%, rendah 30\%, sedang 20\%, tinggi 13,3\% dan sangat tingggi berada pada presentase 0\%. Melihat dari hasil presentase yang ada dapat dikatakan bahwa tingkat hasil belajar siswa sebelum diterapkan metode diskusi tergolong rendah. Selanjutnya nilai rata-rata hasil post-test adalah 87,5 jadi hasil belajar siswa setelah diterapkan pembelajaran konstruktivisme mempunyai hasil belajar yang lebih baik dibanding dengan sebelum penerapan pembelajaran konstruktivisme. Selain itu persentasi kategori hasil belajar bahasa Indonesia siswa juga meningkat yakni sangat rendah yaitu $0 \%$, rendah 10\%, sedang 6,6\%, tinggi 26,6\% dan sangat tingggi berada pada presentase $56,6 \%$. Berdasarkan data yang diperoleh dengan menggunakan rumus uji-t. maka $\mathrm{H}_{0}$ ditolak dan $\mathrm{H}_{1}$ diterima setelah diperoleh $t_{\text {Hitung }}=18,51$ dan $t_{\text {tabel }}=2,04$ maka diperoleh $\mathrm{t}_{\text {Hitung }}>\mathrm{t}_{\text {Tabel }}$ atau 18,51 > 2,04. Dengan demikian, dapat disimpulkan bahwa ada pengaruh penggunaan pembelajaran konstruktivisme pada mata pelajaran bahasa Indonesia di kelas V SD Negeri Mangasa I Kecamatan Somba Opu Kabupaten Gowa.

Saran yang dapat diberikan: (1) Model pembelajaran konstruktivisme diharapkan menjadi masukan bagi guru bidang studi bahasa Indonesia untuk 
mengembangkan kemampuan profesinya. Namun model ini menuntut kepercayaan guru bahwa siswa mampu berkembang dan kreatif dalam menulis, asal gurunya aktif dan kreatif sebagai fasilitator dan moderator dalam pembelajaran menulis. (2) Hendaknya para guru selalu mengaitkan bahan pembelajaran yang sudah ada dengan bahan pembelajaran yang akan dipelajari oleh siswa dan siswa dituntut untuk memetakannya berupa klustering/peta konsep yang memakai preposisi yang menghubungkan antara konsep-konsep yang dipetakannya. (3) Pengembangan penelitian ini disarankan dengan metode penelitian kelas dan studi kasus, sehingga masalah yang dihadapi oleh siswa dalam proses penulisan dapat dipecahkan sesuai dengan situasi dan kondisi sekolah masing-masing.

\section{DAFTAR PUSTAKA}

Akhadiah. 1991. Menulis. Jakarta: Universitas Terbuka

Akhadiah. (1988,1997). Pembinaan kemampuan menulis bahasa Indonesia. Penerbit Erlangga: Jakarta.

Depdiknas. 2006. Kurikulum Tingkat Satuan Pendidikan (KTSP) Bahasa Indonesia Sekolah Menengah Pertama. Jakarta.

Ilman (2013). Meningkatkan Kemampuan Menulis Siswa Mata Pelajaran Bahasa Indonesia dengan Menggunakan Gambar Seri Kelas V SDN 3 Parepare. FKIP Universitas Muhammadiyah Makassar.

Karli, H. dan Yuliariatiningsih, M.S. (2003). Model-Model Pembelajaran. Bandung: Bina Media Informasi.

Mohamad Yunus, Suparno. 2003. Keterampilan Dasar Menulis. Jakarta: Universitas Terbuka.

Paul Suparno. 1997. Filsafat Konstruktivisme dalam Pendidikan. Yogyakarta: Kanisius.

Piaget. (1981). The psychology of Intelligence. Totawa: Littlefield, Adam \& Co.

Poedjiadi, A. (2005). Sains Teknologi Masyarakat; Model Pembelajaran Kontekstual Bermuatan Nilai. Bandung : Remaja Rosdakarya.

Rusniati (2015). Peningkatan Kemampuan Menulis Siswa pada Mata Pelajaran Bahasa Indonesia melalui Model Pembelajaran TTW (Think, Talk, Write) pada Siswa Kelas V SD Inpres Bontoa Kabupaten Gowa. FKIP Universitas Muhammadiyah Makassar. 
Suriamiharja.1996. Menulis sebagai Suatu Keterampilan Berbahasa. Bandung: Angkasa.

Sugiyono. 2013.Metode Penelitian Kuantitatif Kualitatif dan R\&D. Bandung: Alfabeta.

Suparno dan Yunus, M, 2007. Keterampilan Dasar Menulis. Jakarta: Universitas Tebuka.

Suparno dan Muhammad Yunus. 2008. Keterampilan Dasar Menulis. Jakarta: Universitas trerbuka.

Suyatno. 2004. Teknik Pembelajaran Bahasa Dan Sastra. Surabaya: SIC.

Tarigan, Henry Guntur. 1986. Teknik Pengajaran Keterampilan Berbahasa. Bandung: Angkasa.

Tarigan, Djago. 1996. Membina Keterampilan Menulis Paragraf dan Pengembangannya. Bandung: Angkasa

Tarigan, H. G. (2008). Menulis Sebagai Suatu Keterampilan Berbahasa. Bandung: Angkasa.

Yunus, Mohammad. 2006. Keterampilan Dasar Menulis. Jakarta: Universitas Terbuka.

Zainab, Sitti. (2011). Penerapan Model Pembelajaran Konstruktivisme untuk Meningkatkan Kemampuan Menulis Bahasa Indonesia Kelas $V$ SD. FKIP Universitas Muhammadiyah Makassar. 